\title{
A Study on NPA of Public Sector Banks in India
}

\author{
*Sulagna Das, ** AbhijitDutta \\ * Research Scholar KIIT University Bhubaneswar \\ ** Professor, NSHM Business School, Durgapur
}

\begin{abstract}
Non-Performing Assets are a burning topic of concern for the public sector banks, as managing and controlling NPA is very important. The current paper with the help of secondary data, from RBI website, tried to analyse the 6 years, (2008-2013) net non-performing asset data of 26 public sector banks, by using Annova statistics, and with the help of SPSS software. The main objective of the study is to find out if there are any significant differences in the mean variation of the concerned banks. This paper also focuses on the reason behind the NPA and its impact on banking operations.
\end{abstract}

Key Words: Annova, Net Non-Performing Assets

\section{Introduction:}

In the starting when the financial reforms were undertaken by the Government of India based on the Narasimham Committee report I and II, Reserve Bank of India introduced some prudential norms to address the credit monitoring policy, which were being pursued by the banks and other NBFCs. To strengthen the recovery of loans and dues by the banks and the other financial institutions, Government of India in the year 1993, promulgated the 'recovery of debts due to banks and other financial institutions act' and the 'securitisation and reconstruction of financial assets and enforcement of security interest act' in the year 2002.

But statistics shows NPA level is ever increasing day by day, and the said act, which was introduced by the Government of India, is not serving the purpose, they were actually formed. The reason behind it can be the bank's approach and attitude towards financing and recovery of loans especially from the small and medium enterprises and also the lack of knowledge about the law and its practice in banking and also violations of the RBI directives/circulars, which are essential to follow by every bank and financial institutions.(Non-Performing Assets, n. d.)

In the financial year 2013, the non-performing assets had gone up to Rs. 95825 crores, according to the CRISIL report, the gross NPA will increase from $3.3 \%$ on 03.2013 , to $4 \%$ by 03.2014 . An important question is to be answered by the banks and other financial institutions about the recovery of the dues, and banks approach towards focusing on the 'efficiency and fairness' and also become understanding when dealing genuine difficulties in managing the fraud. A strong banking and financial sector is important for a developing economy and the failure of which may have adverse effect on all the sectors.(RBI website, n. d.)

1.1 Non-Performing Asset:Today non-performing assets are the subject of major concerns to the banking sector and the other non-banking financial institutions. A loan or lease that does not meet the stated principal amount and the interest amount payments is termed as non-performing assets. NPA can be classified into commercial loans which are overdue for more than 90 days, and consumer loans which are due for more than 180 days, and rise in NPA is due to the overdue of the commercial loans, there are a lot of pending cases which are being handled by the Indian banks and other financial institutions. (RBI Website, n.d)

Table 1.1: Types of loans and its characters

\begin{tabular}{|l|l|}
\hline Nature of Facility & Parameters \\
\hline Term Loan & Interest and/or instalment of principalremain overdue beyond 90 days \\
\hline Overdraft/Cash Credit & Remains 'out of order'as indicated above \\
\hline Bill Purchased/discounted & Remains overdue beyond 90 days \\
\hline Crop Loans (short duration crops) & Instalment of principal or interest thereon remains overdue for 2 crop seasons \\
\hline Crop Loans (Long duration crops) & Instalment of principal or interest thereon remains overdue for 1 crop season \\
\hline Securitization transactions & Amount of liquidity facility remains outstanding beyond 90 days \\
\hline Derivative transactions & $\begin{array}{l}\text { Overdue receivables representing positive mark-to-market value of a derivative } \\
\text { contract which remains unpaid beyond } 90 \text { days from specified due date for } \\
\text { payment }\end{array}$ \\
\hline Securitisation transaction & Liquidity facility remains outstanding for more than 90 days, \\
\hline
\end{tabular}

Source: http://www.iibf.org.in/documents/IRAC.pdf

\subsection{Definitions of NPA by RBI:}

a) An asset, including a leased asset, becomes non-performing when it ceases to generate income for the bank.

b) A non-performing asset (NPA) is a loan or an advance where; 
i. Interest and/ or instalment of principal remain overdue for a period of more than 90 days in respect of a term loan,

ii. The account remains 'out of order' as indicated at paragraph 2.2 below, in respect of an Overdraft /Cash Credit (OD/CC),

iii. The bill remains overdue for a period of more than 90 days in the case of bills purchased and discounted,

iv. The instalment of principal or interest thereon remains overdue for two crop seasons for short duration crops, the instalment of principal or interest thereon remains overdue for one crop season for long duration crops,

v. The instalment of principal or interest thereon remains overdue for one crop season for long duration crops,

vi. The amount of liquidity facility remains outstanding for more than 90 days, in respect of a securitisation transaction undertaken in terms of guidelines on securitisation dated February 1, 2006.

vii. In respect of derivative transactions, the overdue receivables representing positive mark-to-market value of a derivative contract, if these remain unpaid for a period of 90 days from the specified due date for payment.

c) Banks should, classify an account as NPA only if the interest due and charged during any quarter is not serviced fully within 90 days from the end of the quarter.

d) 'Out of Order' statuses: An account should be treated as 'out of order' if the outstanding balance remains continuously in excess of the sanctioned limit/drawing power. In cases where the outstanding balance in the principal operating account is less than the sanctioned limit/drawing power, but there are no credits continuously for 90 days as on the date of Balance Sheet or credits are not enough to cover the interest debited during the same period, these accounts should be treated as 'out of order'.

e) 'Overdue': Any amount due to the bank under any credit facility is 'overdue' if it is not paid on the due date fixed by the bank. (rbi.org.in)

\subsection{Classification of Assets:}

Non-performing assets are further classified into three categories based on the span for which the asset has remained non-performing and the recovery of the dues:

\section{i. Substandard Assets}

With effect from March 31, 2005, a substandard asset would be the one, which has remained as a nonperforming asset for a period of less than or equal to 12 months. Substandard assets have credit weaknesses that jeopardise the liquidation of the debt and there are also possibility of incurring and sustaining some losses if the deficiencies are not corrected.

\section{ii. Doubtful Assets}

With effect from March 31, 2005, an asset is classified as doubtful if it has remained as a sub-standard asset for a period of 12 months. A loan classified under the doubtful category has all the weakness characteristics as defined for the sub-standard assets; also it has added characteristics that the weakness makes full liquidation or collection, on the basis of the currently known conditions, facts, and values that are highly doubtful and questionable.

\section{iii. Loss Assets}

A loss asset is one where loss has been identified by the bank's internal auditors and RBI's external auditors, but the amount has not been written off fully. These kinds of assets are also considered as uncollectible, and of little value that its continuance or maintenance as a bankable asset is not warranted or acceptable though there may be some salvage or recovery value.(RBI Website, n.d.)

Table: 1.2,Categories and Parameters of NPA

\begin{tabular}{|c|c|c|c|}
\hline No. & Category & Parameters & Provision Requirement \\
\hline 1 & $\begin{array}{l}\text { Substandard } \\
\text { Asset }\end{array}$ & $\begin{array}{l}\text { *Remained NPA for a period not less than or } \\
\text { equal to one year. } \\
\text { *In such cases, the current net worth of the } \\
\text { borrower or guarantor or market value of the } \\
\text { security charged is not enough to ensure } \\
\text { recovery of the bank's dues; } \\
\text { *Likely to sustain some loss if deficiencies are } \\
\text { not corrected. }\end{array}$ & $\begin{array}{l}* 15 \% \text { of the sum of the net investment in } \\
\text { The lease and the unrealized portion of finance } \\
\text { income net of finance charge component. } \\
\text { *Additional } 10 \% \text { for unsecured lease exposure } \\
\text { i.e. total } 25 \% \text {. }\end{array}$ \\
\hline 2 & Doubtful Asset & $\begin{array}{l}\text { *Remained in substandard category beyond } 1 \\
\text { year; } \\
\text { *Recovery - highly questionable and } \\
\text { improbable. }\end{array}$ & $\begin{array}{l}* 100 \% \text { of the finance not secured by the } \\
\text { realizable value of the leased asset. } \\
* \text { Additional provision on the unrealised portion } \\
\text { of finance income net of finance charge } \\
\text { component of the secured portion as under:- }\end{array}$ \\
\hline
\end{tabular}




\begin{tabular}{|l|l|l|l|}
\hline & & & $\begin{array}{l}\text { Period for which the advance remained in } \\
\text { doubtful category and the provision (\%) } \\
\text { Up to one year is } 25 \% \text { provision, } \\
\text { One to three years } 40 \% \text { provision, More than } \\
\text { three years } 100 \%\end{array}$ \\
\hline 3 & Loss Asset & $\begin{array}{l}\text { *Asset considered uncollectible and of little } \\
\text { value but not written off wholly by the bank. } \\
\text { *Continuance as bankable assets although it } \\
\text { may have some salvage or recovery value. }\end{array}$ & $\begin{array}{l}\text { To be written off or 100\% of the sum of the net } \\
\text { investment in the lease and the unrealised portion } \\
\text { of finance income net of finance charge } \\
\text { component. }\end{array}$ \\
\hline
\end{tabular}

Source: http://www.iibf.org.in/documents/IRAC.pdf

1.4 Reasons / Causes of NPA: In the past articles, many authors have found out many reasons for NPA. Few are: Market Failure, Wilful Defaults, Poor follow-up and Supervision, Non-cooperation from Banks, Poor Legal framework, Lack of Entrepreneurial Skills, Diversion of funds (Santanu Das, 2010)Zahoor Ahmad, Dr. M. Jegadeeshwaran (2013) in their paper 'Comparative Study On NPA Management of Nationalised Banks' has analysed, improper selection of borrower's activities, weak credit appraisal system Industrial problem, inefficiency in management of borrower, slackness in credit management and monitoring, lack of proper follow up by bank, recession in the market, and natural calamities and other uncertainties, as the reasons for the NPA. On the other hand (Ashly Lynn Joseph, 2014) in his paper 'A Study on Analyzing the Trend of NPA Level in Private Sector Banks and Public Sector Banks'has identified few external, internal and other factors that are involved in the formation of NPA and those are : diversion of fund for expansion, diversification, modernization or for taking up new projects, diversion of fund for assisting or promoting associate concerns,time or cost overrun during the project implementation stage, business failure due to product failure, failure in marketing etc,inefficiency in bank management, slackness in credit management and monitoring, and inappropriate technology or problems related to modern technology. The external factors include recession in the economy as a whole, input or power shortage, price escalation of inputs, exchange rate fluctuations, and change in government policies. Other factors include liberalization of the economy and the consequent pressures from liberalization like several competitions, reduction of tariffs etc, poor monitoring of credits and failure to recognize early warning signals shown by standard assets, sudden crashing of capital market and inability to raise adequate funds,mismatching of funds i.e. using loan granted for short term for long term transactions, granting of loans to certain sectors of the economy on the basis of government directives rather than commercial imperatives. (Namita Rajput, et.al., 2012) also analysed some reasons behind the formation of NPA, and also found the impact of the NPA on banking operations and (Satpal, 2014) also tried to find out some external factors and some internal factors which affects the NPA like (Ashly Lynn Joseph, 2014), and also found the impacts of NPA.

\section{Review of Literature}

NPA is a burning topic for the banking sector and many authors tried to study the reasons of NPA, the problems created by NPA and the impact of NPA on the banking sector, and moreover came to a solution or remedies of the growing problem of NPA. A number of papers have been written and gone through, and this part of this paper is attempting to present a review of all those are available in the same area of non-performing assets of the public sector banks, private sector banks and other banks. This survey has conducted a study on the existing papers, articles, journals, and reports provided by different authors, groups and committees from time to time.

Dutta. A (2014): This paper studied the growth of NPA in the public and private sector banks in India, and analysed sector wise non-performing assets of the commercial banks. For the purpose of the study data has been collected from secondary sources such as report on Trend and Progress of Banking in India, RBI, Report on Currency and Finance, RBI Economic Surveys of India.

Das, S. (2010): In this paper the author has tried to analyse the parameters which are actually the reasons of NPAs, and those are, market failure, wilful defaults, poor follow-up and supervision, non-cooperation from banks, poor Legal framework, lack of entrepreneurial skills, and diversion of funds

Ahmad, Z., Jegadeeshwaran, M. (2013): The current paper is written on the NPA, and causes for NPA. Secondary data was collected for a period of five years and analysed by mean, CAGR, ANOVA and ranking banks. The banks were ranked as per their performance in managing the NPA"s. The efficiency in managing the NPA by the nationalised banks was tested.

Ranjan, R., Dhal, S.C. (2013): This paper explores an empirical approach to the analysis of the Indian commercial banks' nonperforming loans by regression analysis. The empirical analysis evaluates as to how the NPLs are influenced by three major sets of economic and financial factors, i.e., terms of credit, bank size induced risk preferences and macroeconomic shocks. 
Reddy, P.K. (2002): This paper deals with the experiences of other Asian countries in handling of NPAs. It further looks into the effect of the reforms on the level of NPAs and suggests mechanisms to handle the problem by drawing on experiences from other countries.

Joseph, A. L. (2014): This paper basically deals with the trends of NPA in banking industry, the internal, external and other factors that mainly contribute to NPA rising in the banking industry and also provides some suggestions for overcoming the burden of NPA.

Kamra, S. D. (2013): This paper analyses the position of NPAs in the selected nationalised banks namely State Bank of India (SBI), Punjab National Bank (PNB) and Central Bank of India (CBI). It also focuses on the policies pursued by the banks to manage the NPAs and suggests a strategy for the speedy recovery of NPAs.

Patidar, S.,Kataria, A. (2012): The study analyzed the percentage share of NPA as components of priority sector lending, the comparative study was conducted between SBI and Associates, Old Private Banks and New Private Banks and Nationalized Banks of the benchmark category, to find out the significant difference of the NPA and also find out the significant impact of Priority Sector Lending on the Total NPA of Banks using statistical tools like regression analysis and ratio analysis.

Arora, N., Ostwal, N. (2014): The present paper analyses the classification and comparison of loan assets of public and private sector banks. The study concluded that NPAs are still a threat for the banks and financial institutions and public sector banks have higher level of NPAs in comparison to Private sector banks.

Patnaik, B.C.M., Satpathy,I. (2012): The present paper made an attempt to analyse the causes of NPAs in working capital loans of Urban Co-operative banks. For the study purpose borrowers were surveyed through questionnaires, causes were analyzed and suggestions made to overcome the problem.

Patnaik, B.C.M., Satpathy, I. (2011): The present paper tries to analyze the quantitative trend and pattern in growth of NPA with reference to the education loan scheme, in Odisha. An effort was made to find the cause, by questionnaire survey of the defaulters, who are students of different colleges, suggestions to overcome this problem was also given by the author.

Bhatia, B.S., Waraich, S., Gautam, V. (2013): This study was made on District Central Cooperative Bank of Punjab, the study tried to analyse the impact of some new product lines on non performing advances in cooperative banks and trends in NPA against loan schemes. Lastly a comparative analysis was made between bank wise and component wise to find out the lacunas and suggest measures for improvement in managing NPA.

Rajput, N., Gupta, M., Chauhan, A.K. (2012): This paper provides an empirical approach to the analysis of profitability indicators on NPA, it also discusses the factors which contribute towards NPA, and also analyses the solution for the same. All empirical findings were done by using statistical tools like correlation, regression and data representation techniques and DEA.

Ibrahim, M.S.,Thangavelu, R. (2014): In this paper, the author has analyzed the concept of NPAs, components of loan assets in public sector, private sector and other foreign banks, by an exploratory and diagnostic approach with the help of secondary data.

Srinivas, K.T. (2013): The present paper undertakes to study the reasons for loans and advances becoming NPA in the Indian Commercial banking Sector and give a suitable solution to overcome the mentioned problem.

Rai, K. (2012): The paper made an effort to evaluate the operational performance of the selected commercial banks, and the NPA Trends and issues, also the measures taken for managing the NPAs like reformulation of banks' credit appraisal techniques, establishment of monitoring department, etc.

Satpal (2014): An attempt has been made in this paper to find out the actual definition of NPA and the factors contributing to the formation NPAs, reasons for high NPAs and their impact on Indian banking operations.

Rajeev, M., Mahesh, H.P., (2010): This exploratory paper examines the Indian trends of NPAs from various dimensions and explains how recognition of the problem continuous monitoring, can reduce it to a greater extent. The paper also discusses the functions of the joint liability groups or self help groups in enhancing the loan recovery rate.

Yadav, S. (2014): With the help of secondary data, the author in the present paper has tried to show the recent trends and its preventive measures to control NPAs in Indian banking industry.

Rakshit, D.,Chakrabarti, S. (2012): The paper deals with understanding the extent of NPAs in cooperative bank and the major causes behind an account becoming non-performing in cooperative banks

Kumar, M.,Singh, G. (2012): The paper focuses on the most significant factors, which contribute towards the non-performing assets problem from the view point of the top bankers of public sector banks and, some foreign banks in India and the measures required for managing the NPAs

Gupta, J., Jain, S. (2012): The present study deals with performance and the lending practices of some successful cooperative banks of Delhi, whose customers have taken more than one type of loans from the bank.

Pradhan, T.K. (2012): The present study is on Odisha, and depends on the mismanagement or diversion of fund, which are one of the main causes of NPA. The study is based on primary data which has been analyzed by percentage method. The data was collected from 50 bank officials through a structured questionnaire. 
Rajput, N.,Arora, A.P., Kaur, B. (2012): This study focuses on management of non-performing assets of the public sector banks under stringent asset classification norms. The study tried to trace the movement of the nonperforming assets present in Indian public sector banks and also analysed the performance of the banks in managing the NPA.

Rajaraman, I.,Vasishtha, G. (2001): The paper performs a panel regression on the definitional uniform secondary data, on NPA available for a five-year period ending in 1999-2000. The paper studies 27 public sector banks, and investigates variations within a class that is homogenous on the ownership dimension and operational efficiency.

Gupta, B. (2012): In this paper, study has been made on SBI and Associates, and public sector banks, an effort has been made to understand the concept of NPAs, its magnitude and major causes for increasing NPA and also evaluate the operational performance in managing NPA.

Rajput, N.,Arora, A.P., Kaur, B. (2011): This study attempts to trace the movement of the NPAs presence in public sector banks of India, by analyzing the financial performance in managing NPA.

Ganesan, D., Santhanakrishnan, R. (2013): In this paper, an effort has been made to evaluate the nonperformance assets of the SBI since 2002.

Stuti, Bansal, S. (2013): In this paper, an effort has been made to evaluate the operational performance of the Public Sector Banks and Private sector bank in India with the help of secondary data between 2003-04 and 2007-09, on NPAs Trends and issues. This paper analyzes how efficiently Public and Private sector banks have been managing NPA.

Pradhan, T.K. (2012): The present study, with the help of secondary data of six years, tried to analyse how reform measures helped in minimising the NPA in public sector banks, the data has been analyzed by using percentage method.

Selvarajana, B.,Vadivalagan, G. (2013): The present study has been designed to illustrate the necessity and the nature of the non-performing assets in Indian Bank, Tamil Nadu. The study was done on the priority sector loan.

Tripathi, L. K., Parashar, A., Mishra, S. (2014): The present study, with the help of multiple regression model attempts to investigate the impact of priority sector advances, unsecured advances and advances made to sensitive sectors by banks like SBI group and other nationalised banks on Gross NPAs of banks.

Jajashree, Kotnal, R., Ahmed, I.,Naikwadi, M. (n.d.): This study deals with understanding the concept of NPAs, its magnitude and major causes for an account becoming non-performing, the study was made on Corporation Bank, Bagalakot and BDCC Bank, Bagalakot.

Kaur, H., Saddy, N.K. (2011): An attempt was made in the paper to know about NPA, the factors responsible for the contribution towards NPAs, the magnitude and reasons for high NPAs and their impact on Indian banking operations.

Satpathy, I, Patnaik, B.C.M. (2010): The present paper attempted to examine the causes of NPAs in home loans of commercial banks. For this borrowers of the loans were surveyed through questionnaires made for the purpose, and ultimately suggestions given to overcome the problem.

Chaudhary, K., Sharma, M. (2011): This paper has made an attempt to analyze how efficiently Public and Private sector banks have been managing NPA. A statistical tool for projection of trend was used for analysis.

\section{Gap in Research}

From the above literature review it was found that no study has been conducted from the period 2008 to 2013 in context of the objective stated earlier in the study. So the present scenario of Net NPA of banking sector was not depicted by the above researcher.

\section{Statement of the Problem:}

The study tries to discuss the reasons of the NPA in public sector banks and also analyses the problems, with a suitable solution. The main subject matter of this paper is to understand the significant difference of the NPA occurrence, and management of NPA in different nationalized banks of India in respect to priority and non-priority sector lending.

\section{Need of the Study}

The banking sector of India consists of public sector banks, private sector banks, co-operative banks and foreign banks. But among these four types' public sector banks still dominate the banking industry, with approximate $82 \%$ of the market share in total deposit and advances of the industry. The public sector banks play a crucial role in the Indian economy, by contributing directly to the GDP, and mobilizing savings and channelizing investments. But after managing every challenge successfully and by giving standard services to the customers, NPA becomes the biggest of all challenges and managing NPA is one of the hardest tasks for 
these banks, as the increasing NPA have adverse impact upon the progress of the Indian economy and the Indian financial system. On the other hand NPA is efficiently managed by the private sector banks, and it is controlled.

The current paper tries to draw a view on the status of the NPA in different public sector banks, including State Bank of India and its Associates, and other public sector banks.

\section{Objective of the study:}

The objective of the study is to find out whether there is any difference in the NPA occurrence between the various banks during the period of the study.

\section{Scope:}

The scope of the study is in between the financial year 2008-2013on the public sector banks, which include the State Bank of India and its Associates, and the other Nationalised banks of India.

\section{Research Methodology}

The present study is done on the SBI Associate Banks and other public sector banks. The SBI Associate Banks include: The State Bank of India, State Bank of Bikaner and Jaipur, State Bank of Hyderabad, State Bank of Mysore, State Bank of Patiala, and State Bank of Travancore. The other public sector banks include Allahabad Bank, Andhra Bank, Bank of Baroda, Bank of India , Bank of Maharashtra, Canara Bank, Central Bank of India, Corporation Bank, Dena Bank, IDBI Bank Limited, Indian Bank, Indian Overseas Bank, Oriental Bank of Commerce, Punjab and Sind Bank, Punjab National Bank, Syndicate Bank, UCO Bank, Union Bank of India, United Bank of India, Vijaya Bank.

The Net Non-Performing Asset for six years, starting from 2008 to 2013, is analysed. The study is done based on the secondary data, which is obtained from published report of RBI and other articles and journals.

Net Non-Performing Assets = Gross NPA $-($ Balance in Interest Suspense account + DICGC/ECGC claims received and held pending adjustment + Part payment received and kept in suspense account + Total provisions held) (rbi.org.in)

The figures of NNPA which are obtained from the reports of RBI, have been analysed with SPSS software, and statistical tool, "analysis of variance" or Annova.

The data sheet is given below:

Table 1.3: NNPA values of SBI and Associates:

\begin{tabular}{|l|l|l|l|l|l|l|}
\hline & $\mathbf{2 0 0 8}$ & $\mathbf{2 0 0 9}$ & $\mathbf{2 0 1 0}$ & $\mathbf{2 0 1 1}$ & $\mathbf{2 0 1 2}$ & $\mathbf{2 0 1 3}$ \\
\hline State Bank of India & 1.78 & 1.79 & 1.72 & 1.63 & 1.82 & 2.10 \\
\hline $\begin{array}{l}\text { State Bank of Bikaner and } \\
\text { Jaipur }\end{array}$ & .83 & .85 & .78 & .83 & 1.92 & 2.27 \\
\hline State Bank of Hyderabad & .16 & .38 & .55 & .87 & 1.30 & 1.61 \\
\hline State Bank of Mysore & .43 & .50 & 1.02 & 1.38 & 1.93 & 2.69 \\
\hline State Bank of Patiala & .60 & .60 & 1.04 & 1.21 & 1.35 & 1.62 \\
\hline State Bank of Travancore & .94 & .58 & .91 & .98 & 1.54 & 1.46 \\
\hline
\end{tabular}

Source: rbi.org.in

Table 1.4: NNPA values of Other Public Sector Banks:

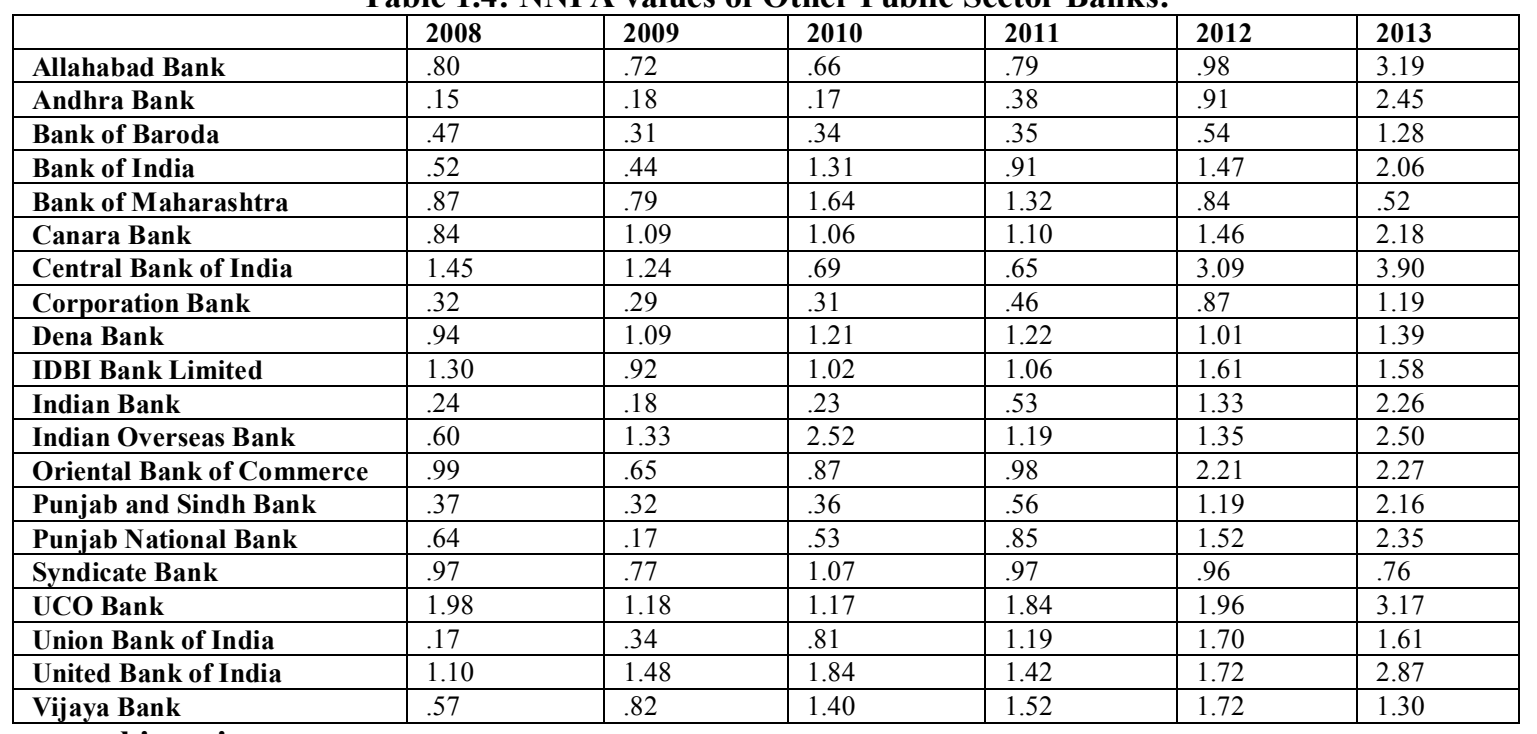

Source: rbi.org.in 


\section{Research Design: Statistical Method Used}

For the purpose of the study analysis of variance (ANOVA) one way has been used. The linear mathematical model as given below has been used.

$\mathrm{Xij}=\boldsymbol{\mu}+\boldsymbol{\alpha}_{\mathrm{i}}+\boldsymbol{\varepsilon}_{\mathrm{ij}} \ldots \ldots \ldots \ldots \ldots \ldots \ldots \ldots . . . \ldots$ Equation (1)

Where,

$\mathrm{Xij}=$ The yield from the jth row, $\left(j=1,2 \ldots \mathrm{n}_{\mathrm{i}}\right)$ fed on the ith ration $(I=1,2, \ldots \ldots, \mathrm{k})$

$\mu=$ General mean effect given by

$\mathrm{k}$

$\mu=\sum n_{i} \mu / n$

$\alpha_{\mathrm{i}}=$ The effect of the ith ration given by

$\alpha_{\mathrm{i}}=\mu_{\mathrm{i}}-\mu,(\mathrm{i}=1,2, \ldots . \mathrm{k})$

$\varepsilon_{\mathrm{ij}}=$ The error effect due to chance.

Assumption of the model.

i. All the observations $X_{i j}$ are independent and $X_{i j} \sim N\left(\mu_{i j}, \sigma_{e}^{2}\right)$

ii. Difference effects are additive in nature

iiii. $\varepsilon_{\text {ij }}$ are i.i.d, $\mathrm{N}\left(0, \sigma_{\mathrm{e}}{ }^{2}\right)$

9.1. Hypothesis:

H0: There is no significant difference in mean variation between the NPAs of the banks

H1: There is significant difference in mean variation between the NPAs of the banks

9.2. Limitations: The study is concerned with all the published NPA by the Reserve Bank of India. It doesn't probeinto the NPA management nor does it try to find causation for these factors.

\section{Analysis and Interpretation:}

The whole study and the analysis are done on these banks, there are 26 banks, and each bank is given a number, from 1 to 26 . The NNPA of Allahabad Bank is written under variable 2 column, and number ' 1 ' for Allahabad Bank id written under, variable1, or VAR00001, NNPA of Andhra Bank for the 6 years (2008-2013) is written under variable 2, or VAR00002, and number ' 2 ' is written for Andhra Bank, a series of 6, twos (2) are written under VAR00001 column, it continues and like this way, the each of the $26 \mathrm{banks}$, are given a number of 1-26, and are written under VAR00001 column, and the values of NNPA for 6 years, per bank is written under the VAR00002 column. Number 1 is for Allahabad Bank, and number 26 is used for State Bank of Travancore. Each number has a group data of NNPA, for a single bank, for 6 years. Univariate test is done for these 26 banks to find if there is any significant mean variation between the NNPAs of the banks. Variable 1 or VAR00001 is considered as dependent factor, and Variable 2 or VAR00002 is considered as fixed factor for the analysis purpose.

It is known that if F-statistics is greater than $\mathrm{P}$ then null hypothesis will be rejected, and alternate hypothesis will be accepted, but if F-statistics is less than $\mathrm{p}$, then null hypothesis will be accepted and alternate hypothesis will be rejected. So If $\mathrm{F}>\mathrm{P}$, there will be significant difference in mean variation of the NPAs of the public sector banks but if and therefore $\mathrm{H} 0$ will be rejected, and $\mathrm{H} 1$ will be accepted, on the other hand if $\mathrm{F}<\mathrm{P}$, there will be no significant difference in mean variation, and therefore $\mathrm{H} 0$ will be accepted and $\mathrm{H} 1$ will be rejected.

The table below labelled tests of between subjects' effects gives the Annova results.

\section{Results after analysis:}

Table 1.5: Tests of Between-Subjects Effects

\begin{tabular}{|c|c|c|c|c|c|c|}
\hline $\begin{array}{l}\text { Corrected Model } \\
\text { Intercept } \\
\text { VAR00002 } \\
\text { Error } \\
\text { Total } \\
\text { Corrected Total }\end{array}$ & $\begin{array}{l}6159.917^{\mathrm{a}} \\
24084.764 \\
6159.917 \\
2615.083 \\
37206.000 \\
8775.000\end{array}$ & $\begin{array}{l}110 \\
1 \\
110 \\
45 \\
156 \\
155\end{array}$ & \begin{tabular}{|l|}
55.999 \\
24084.764 \\
55.999 \\
58.113
\end{tabular} & $\begin{array}{l}.964 \\
414.447 \\
.964\end{array}$ & $\begin{array}{l}.573 \\
.000 \\
.573\end{array}$ & $\begin{array}{l}.702 \\
.902 \\
.702\end{array}$ \\
\hline
\end{tabular}

a. R Squared $=.702$ (Adjusted R Squared $=-.026$ ) Source: SPSS Output 
We can see that the F-statistics corresponding VAR0002 is .964, which is significant at $\mathrm{P}<.573$, now as $\mathrm{F}=.964>\mathrm{P} .573$, it can be said that, there is significant mean variation between the NPAs of the public sector banks. There null hypothesis is rejected and alternate hypothesis is accepted.

\section{Conclusion}

NPA or Non-Performing Assets are the types of assets whichare the subject of major concerns to the banking sector and the other non-banking financial institutions. A loan or lease that does not meet the stated principal amount and the interest amount payments is termed as non-performing assets. The current study deals with the types of NPA and its causes as well as its impact on the banking sector and the economy as a whole. A study was done on the State Bank of India and its associates, and the other public sector banks, based on the secondary data, from the annual reports, of 6 years starting from 2008 to 2013. An attempt is made to analyse the data, through statistical tool, ANOVA.

The main objective of the study was to find out whether there is any difference in the NPA occurrence between the various banks during the period of the study. The study finds out that there is no significant deference between the means of NPA of the banks at five percent level of significance. Hence one can safely conclude that banks irrespective of their operations have similar NPAs in the recent years.

\section{Reference:}

[1]. Dutta, A (2014) Empirical Study On Non-Performing Assets Management Of Indian Commercial Sector Banks. Retrieved from, Perspective, Vol 6, no. 2. Pp. 18-22

[2]. Das, S (2010) Management of Non-Performing Assets In Indian Public Sector Banks With Special Reference To Jharkhand. Retrievied from http://www.igidr.ac.in/newspdf/money/mfc_10/Santanu\%20Das_submission_45.pdf

[3]. Ahmad, Z., Jegadeeshwaran, M. (2013) Comparative Study On NPA Management Of Nationalised Banks. Retrieved from International Journal of Marketing, Financial Services and Management Research, ISSN 2277- 3622, Vol.2, No. 8, August (2013)

[4]. Ranjan, R, Dhal, S.C. (2003) Non-Performing Loans and Terms of Credit of Public Sector Banks in India: An Empirical Assessment. Retrieved from Reserve Bank of India Occasional Papers, Vol. 24, No. 3, Winter 2003

[5]. Reddy, P. K. (2002) A comparative study of Non-Performing Assets in India in the Global context - similarities and dissimilarities, remedial measures. Retrieved from http://papers.ssrn.com/sol3/papers.cfm?abstract_id=361322

[6]. Joseph, A.L., Prakash, M (2014) A Study on Analyzing the Trend of NPA Level in Private Sector Banks and Public Sector Banks. Retrieved from International Journal of Scientific and Research Publications, Volume 4, Issue 7, July 20141 ISSN 2250 3153

[7]. Samir, Kamra, D., (2013) A Comparative Analysis of Non- Performing Assets (NPAs) of Selected Commercial Banks in India Opinion: Retrieved from International Journal of Management, Vol. 3, No. 1, June 2013, ISSN: $2277-4637$ (Online) | ISSN: 2231 5470 (Print)

[8]. Patidar, S., Kataria, A. (2012), Analysis OfNpa In Priority Sector Lending: A Comparative Study Between Public Sector Banks And Private Sector Banks Of India. Retrieved from Bauddhik Volume 3, No.-1, Jan-April-2012

[9]. Arora, N, Ostwal,N (2014),Unearthing The Epidemic Of Non-Performing Assets: A Study Of Public And Private Sector Banks. Retrieved from SMS Varanasi, Vol. X, No. 1; June 2014

[10]. Bartaria,I, Parveern,S (2014) Some Perspectives of Banking Industry in Global Scenario. Retrieved from International Journal Of Engineering Research and Management Technology, May- 2014 Volume 1, Issue 3 ISSN: 2348-4039

[11]. Patnaik, B.C.M., Satpathy, I, Patnaik,N (2012) Decoding The Npas In Working Capital Loan: A Survey (With Special Reference To Urban Co-Operative Banking Organizations' In Selected Districts Of Odisha) Retrieved from IJRFM Volume 2, Issue 5 (May 2012) (ISSN 2231-5985)

[12]. Patnaik, B.C.M, Satpathy, I, Mohapatra, A.K.(2011) Demystifying Npas On Education Loan: A Survey (With Special Reference To Selected Urban, Rural Areas And Bank Officials Of Odisha). Retrieved from JBFSIR Volume 1, Issue 4 (July, 2011 ) ISSN 2231 4288

[13]. Bhatia1, B.S., Waraich, S, Gautam, V (2013) Critical Evaluation Of Non-Performing Advances In Dccbs Of Punjab. Retrieved from Abhinav International Monthly Refereed Journal of Research In Management and Technology, ISSN - 2320-0073 Volume II, July'13

[14]. Rajput, N., Gupta,M., Chauhan, A.K. (2012) Profitability And Credit Culture Of NPAs: An Empirical Analysis Of Psbs Retrieved from International Journal of Marketing, Financial Services and Management Research, Vol.1 Issue 9, September 2012,

[15]. Ibrahim, M.S., Thangavelu,R (2014), A Study on the Composition of Non-Performing Assets (NPAs) of Scheduled Commercial Banks in India. Retrieved from Journal of Finance and Bank Management, March 2014, Vol. 2, No. 1,

[16]. K T, Srinivas (2013),A Study On Non- Performing Assets Of Commercial Banks In India. Retrieved from Abhinav International Monthly Refereed Journal of Research In Management and Technology,Volume II, December'13 ISSN - 2320-0073

[17]. Rai,K (2012) Study On Performance Of NPAs Of Indian Commercial Banks. Retrieved from AJRBF, Volume 2, Issue 12 (December, 2012) ISSN: 2249-7323

[18]. Satpal (2014),A Comparative study of Non-Performing Assets in Public and Private Sector Banks in the New Age of Technology. Retrieved from International Journal of Current Engineering and Technology, Vol.4, No.4 (Aug 2014), E-ISSN 2277 - 4106 , PISSN 2347 - 5161,

[19]. Rajeev, M., Mahesh, H.P. (2010) Banking Sector Reforms and NPA: A study of Indian Commercial Banks (Working Paper 252 ). Retrieved fromhttp://www.isec.ac.in/WP\%20252\%20-\%20Meenakshi\%20Rajeev\%20and\%20H\%20P\%20Mahesh.pdf

[20]. Yadav, S (2014) NPAs: Rising Trends and Preventive Measures in Indian Banking Sectors. Retrieved from Volume 2, Issue 1, January 2014, International Journal of Advance Research in Computer Science and Management Studies, ISSN: 2321 -7782

[21]. Rakshit, D, Chakrabarti, S. (2012). NPA Management of Rural Cooperative Banks of West Bengal: An Overview. Retrieved from Volume-I, No.-3, January -- June 2012 Business Spectrum ISSN-2249-4804

[22]. Kumar,M., Singh,G (2012)Mounting Npas In Indian Commercial Banks. Retrieved from International Journal of Transformations in Business Management, (IJTBM) 2012, Vol. No. 1, Issue No. 6, Apr-Jun ISSN: 2231-6868

[23]. Gupta,J., Jain, S.,(2012) A study on Cooperative Banks in India with special reference to Lending Practices. Retrieved from International Journal of Scientific and Research Publications, Volume 2, Issue 10, October 2012, ISSN 2250-3153 
[24]. Pradhan, T.K. (2012) Management of NPA in the Commercial Banks in Odisha: An Empirical Analysis. Retrieved from International Journal of Scientific and Research Publications, Volume 2, Issue 9, September 2012, ISSN 2250-3153

[25]. Rajput, N., Arora, A.P., Kaur, B (2012) Management Of Non-Performing Assets A Study Of Indian Public Sector Banks. Retrieved from IJMIE Volume 2, Issue 4, April 2012, ISSN: 2249-0558

[26]. Rajaraman, I., Vasishtha, G. (2001) Non-Performing Loans of PSU Banks: Some Panel Results (Discussion Paper), November2001

[27]. Gupta, B. (2012) A Comparative Study of Non-Performing Assets of SBI and Associates and Other Public Sector Banks. Retrieved from SIT Journal of Management, Vol. 2.No. 2. December 2012.

[28]. Rajput, N., Arora, A.P., Kaur, B (2011) Non-performing assets in the Indian public sector banks: an analytical study. Retrieved from Banks and Bank Systems, Volume 6, Issue 4, 2011

[29]. Ganesan, D., Santhanakrishnan, R., (2013) Non-Performing Assets: A Study Of State Bank Of India. Retrieved from Asia Pacific Journal Of Research, October 2013, Volume: I, Issue: X

[30]. Stuti, Bansal, S., (2013) An Analysis Of Non- Performing Assets In Indian Banking Sector. Retrieved from Vignettes of Research,Volume - I, Issue - IV ISSN : 2320 - 1797 October - 2013

[31]. Pradhan, T.K. (2012). Non-Performing Assets (NPA) - A major source of weakness of Public Sector Banks. Retrieved from RJCBS: Volume: 01, Number: 12, October-2012

[32]. Selvarajana, B., Vadivalagan, G., (2013) A Study on Management of Non-Performing Assets in Priority Sector reference to Indian Bank and Public Sector Banks (PSBs). Retrieved from International Journal of Finance and Banking Studies IJFBS, Vol.2 No.1, 2013 ISSN: $2147-4486$

[33]. Tripathi, L. K., Parashar, A, Mishra, S., (2014) A Comparative Study Of Advances Contributing To Non-Performing Assets Between Sbi Group and Nationalised Banks. Retrieved from International Journal Of Marketing, Financial Services and Management Research, ISSN 2277-3622, IJMFSMR, Vol.3 (7), JULY (2014)

[34]. Kotnal, J.R., Ahmed, I., Naikwadi, M(2012) A Study On Management Of Non-Performing Assets In District Central Cooperative Bank Retrieved from http://elkjournals.com/masteradmin/uploadfolder/1.\%20a\%20study\%20

[35]. Kaur, H., Saddy, N.K. (2011) A Comparative Study Of Non-Performing Assets Of Public And Private Sector Banks. Retrieved from International Journal Of Research In Commerce and Management, Volume No. 2 (2011), Issue No. 9 (September) Issn 09762183

[36]. Satpathy, I., Patnaik, B.C.M., Pradhan, P.K., (2010) NpasIn Home Loan: A Survey (With Special Reference To Selected Districts Of Odisha). Retrieved from International Journal Of Research In Commerce and Management, Volume No: 1 (2010), Issue No. 8 (December) Issn 0976-2183

[37]. Chaudhary, K., Sharma, M., (2011) Performance of Indian Public Sector Banks and Private Sector Banks: A Comparative Study International Journal of Innovation, Retrieved from Management and Technology, Vol. 2, No. 3, June 2011

[38]. RBI Website (n.d.) Retrieved from www.rbi.org.in

[39]. Master Circular (2013) Retrieved from http://rbidocs.rbi.org.in/rdocs/notification/PDFs/62MCIRAC290613.pdf

[40]. Prudential Norms On Income Recognition, Asset Classification (n.d.) Retrieved from http://www.iibf.org.in/documents/IRAC.pdf

[41]. Non Performing Assets (n.d.) Retrieved from http://www.blsdetectives.com/npa.html 